\title{
Bioacoustics of human whistled languages: an alternative approach to the cognitive processes of language
}

\author{
JULIEN MEYER \\ Laboratoire de Dynamique du Langage (DDL)-CNRS, Institut des Sciences de l'Homme (ISH) \\ 14 Avenue Berthelot, 69363 Lyon Cedex 07, France \\ Manuscript received on January 15, 2004; accepted for publication on February 5, 2004.
}

\begin{abstract}
Whistled languages are a valuable heritage of human culture. This paper gives a first survey about a new multidisciplinary approach to these languages. Previous studies on whistled equivalents of languages have already documented that they can provide significant information about the role of rhythm and melody in language. To substantiate this, most whistles are represented by modulations of frequency, centered around $2000 \mathrm{~Hz}( \pm 1000 \mathrm{~Hz})$ and often reach a loudness of about $130 \mathrm{~dB}$ (measured at $1 \mathrm{~m}$ from the source). Their transmission range can reach up to $10 \mathrm{~km}$ (as verified in La Gomera, Canary Island), and the messages can remain understandable, even if the signal is deteriorated. In some cultures the use of whistled language is associated with some "talking musical instruments" (e.g. flutes, guitars, harps, gongs, drums, khens). Finally, whistles as a means of conveying information have some analogues in the animal kingdom (e.g. some birds, cetaceans, primates), providing opportunities to compare the acoustic characteristics of the respective signals. With such properties as a reference, the project reported here has two major tasks: to further elucidate the many facets of whistled language and, above all, help to immediately stop the process of its gradual disappearance.
\end{abstract}

Key words: human whistled languages, whistle communication, cognitive processes, cultural universals.

\section{INTRODUCTION}

Besides spoken language, some populations in different parts of the world use a complementary system of vocal communication, which is based on modulated whistles and thus called 'whistled language'. Whistled languages can be regarded as a transposition of a given local language into a repertoire of whistles. Almost any language (non-tonal, tonal or accent-pitch) could be whistled and nearly anything can be expressed this way. Such adaptations have been used by various cultures, mainly in response to a specific ecological situation: a cer-

E-mail: Julien.Meyer@etu.univ-lyon2.fr tain isolation of individuals in their everyday activities. Therefore they are mostly used in mountains or dense forests.

Reports about whistled languages were documented since the treaty of the Tao in Asia $\left(6^{\text {th }}\right.$ century B.C.) and since the $17^{\text {th }}$ century in the island of La Gomera (Canary Islands). First studies concerned mainly anthropological aspects (Quedenfeldt 1887, Lajard 1891, Labouret 1923, Eboué 1935), whereas later investigations also included linguistic (Cowan 1948, Classe 1956) and acoustical issues (Busnel 1966, 1970b). Today, twelve whistled languages have been partially described and studied linguistically or bioacoustically (see Sebeok and 
Umiker-Sebeok 1976). In addition, as many as sixty other languages are suspected to still have a whistled equivalent, but these have not been studied yet.

\section{GEOGRAPHICAL AND CULTURAL DISTRIBUTION}

The spatial distribution of whistled languages is associated with special conditions of human communication, particularly (a) long distance between people living in places where rugged topography separates them in terms of travel times, even when they may be in visual contact (which results in a certain isolation of individuals), or (b) local secrecy in speaking about the environment (e.g. for hunting or fishing) or about others (e.g. in terms of love, religious, political or social matters).

The twelve whistled languages that currently have been described and studied in linguistic or bioacoustic approaches can be listed in Table I.

Many other examples have been described in articles either by travelers, conquistadores, anthropologists or ethnomusicologists. Southern China, Papua New Guinea, the Amazon forest, SubSaharan Africa and Mexico encompass most of these languages. They are generally of everyday use but are often endangered.

\section{LiNGUISTIC RANGE}

The whistled languages have a linguistic extent that reflects totally the basic knowledge of the population in the vocal spoken language. The linguistic range of these languages is therefore not physically limited, but only culturally, just like for spoken languages.

\section{Dialects}

Through the signal of the whistled languages, different dialects from a village to another can often be recognized. For example, in the Mazateco culture of Oaxaca, Mexico, 14 different variations of the Mazateco language exist in the highlands, where we were able to record four of them in whistled versions (Tenango, Eloxochitlan de Flores Magon, Huautla and San Mateo). They reflect the differences among vocabularies resulting from various contacts with other languages and the differences of evolution in the valleys.

\section{SignATURE}

The whistles mediate many different messages: the gender of the whistler, his/her age (as we could verify it by a perception test in the Mazateco language), his/her mood (to a certain extent) and, in most of the cases, the identity of the whistler, i.e. the signature of his/her voice.

\section{Link With TALKing Musical Instruments (TMI)}

In locations where whistled languages are still very developed like in South China, they occur often tightly linked to talking musical instruments [flutes, local guitars, harps, drums (Fig. 1), gongs, khen (small and tall)]. The whistles as well as the instruments are used indifferently for speaking or for playing music in bands. They have a key position in every popular ceremony because the messages they convey represent the living memory of their oral culture. For example when somebody has died or is born, they are used to tell the life of the dead or of the ancestors of the newborn to other villages. Therefore they are one of the main means of cultural transmission (Xian-Ming 2002).

\section{PHYSICAL CHARACTERISTICS OF THE SIGNAL}

The whistle is most of the time either practiced with one finger in order to reach high levels of power for long distance speaking (Fig. 2), or directly with the lips for the short distance discussions (Fig. 3) and sometimes with a leaf. The whistles are represented by modulations of frequency, centered around $2000 \pm 1000 \mathrm{~Hz}$ (Fig. 4). At a distance of one meter from the mouth of the whistler, they can reach an amplitude of $130 \mathrm{~dB}$. Variations of amplitude levels follow approximately those of frequency. This indicates that the whistler has to increase the air pressure to raise the pitch of the whistle.

In general, there is a concentration of the information within a relatively short band of frequency compared to spoken language. This explains both 
TABLE I

\begin{tabular}{l|l}
\hline Whistled languages & Authors \\
\hline $\begin{array}{l}\text { Silbo, on the small island of } \\
\text { La Gomera (Canary Islands) }\end{array}$ & $\begin{array}{l}\text { Classe (1956, 1957, 1963), Busnel and Classe (1976), } \\
\text { Busnel and Siegfried (1990), Trujillo (1978), } \\
\text { Rialland and Gautheron (2000) }\end{array}$ \\
\hline Aas, in the French Pyrénées & Busnel et al. (1962a, b) \\
\hline Kusköy, in Turkey & $\begin{array}{l}\text { Busnel (1970a, b), Lenneberg (1970), Leroy (1970), } \\
\text { with M. Moles and B. Vallancien }\end{array}$ \\
\hline Evia, in Greece & Charalambakis (1993) \\
\hline Abu'-Wam, in Papua New Guinea & Nekitel (1992) \\
\hline Tepehua, in eastern Mexico & Cowan (1952, 1972, 1976, 1981) \\
\hline Mazateco, in Mexico & Cowan (1948, 1952), Busnel (1981) \\
\hline the H'mongs, in Vietnam and Guyana & Busnel ( pers. comm. 2003) \\
\hline the Bai, in Yunnan, China & Xian-Ming (2002) \\
\hline the Chepang of Nepal & Caughley (1976) \\
\hline Diola language of Casamance, Sénégal & Moreau (1997) \\
\hline
\end{tabular}

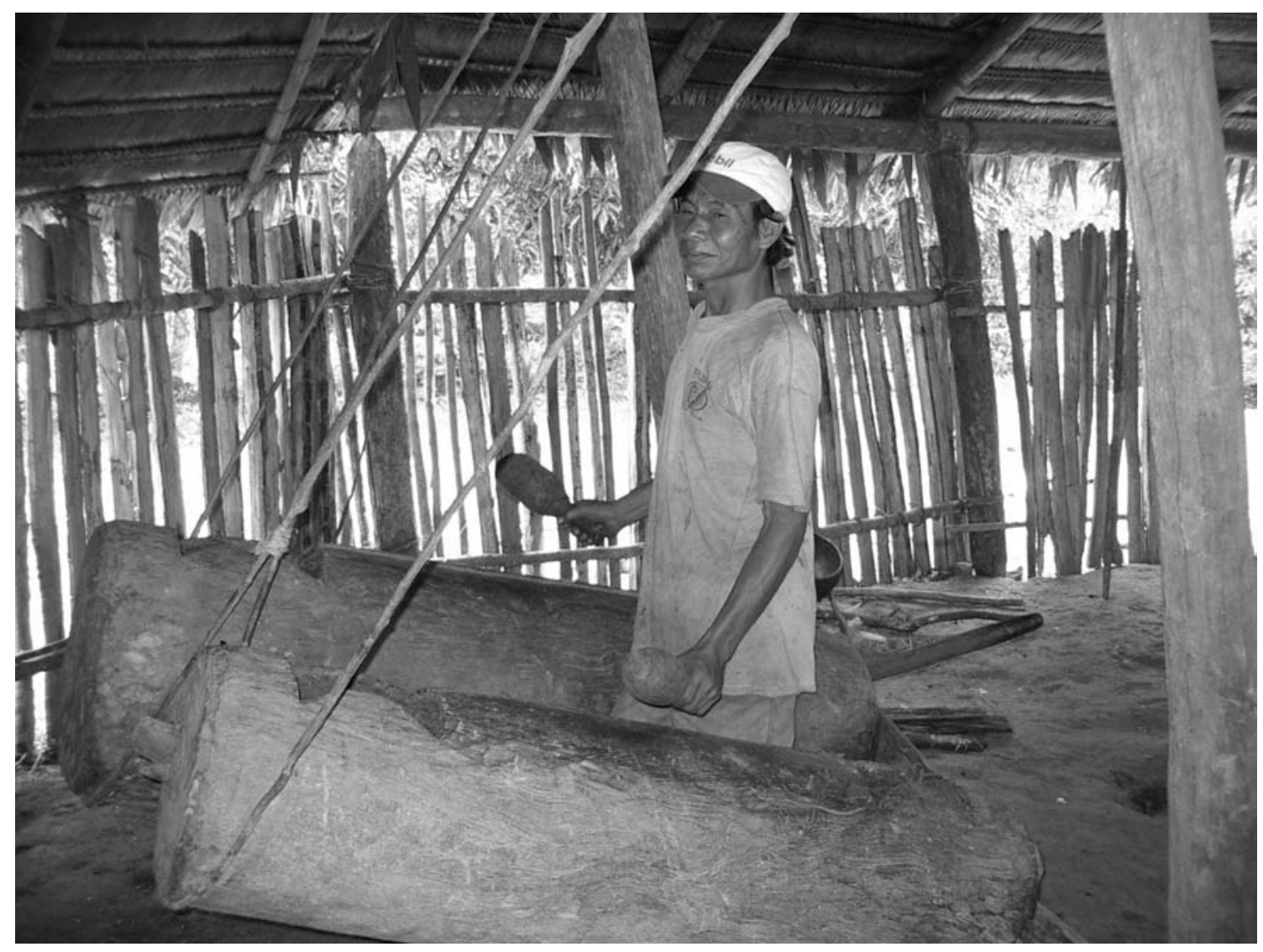

Fig. 1 - Manuel Ruis Mibeco, a Bora shaman playing on the Manguarey (double slit drum). 


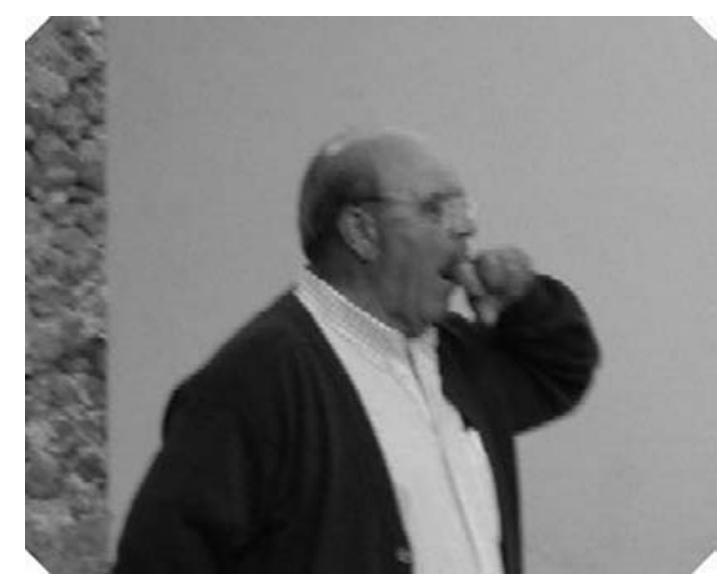

Fig. 2 - Maestro de Silbo of La Gomera showing to a class of children how to use the finger to whistle.

its use in conditions of noise or isolation and the efficiency of the whistles at long distance. Such properties increase the signal's resistance against reverberation. In the mountains of La Gomera whistles can travel up to $10 \mathrm{~km}$, yet the messages can still remain understandable, even if, at this distance, the signal deteriorates (Busnel and Classe 1976).

In summary, the whistled forms of language seem to encode the essential part of human language by an apparently simple signal that is constituted by one main band of frequency, which survives propagation over a long distance.

\section{LINGUISTIC CONSIDERATIONS}

The whistled forms of languages are far more than a code or conventional signalization system with stereotyped sentences as they sometimes have been described. They work exactly like vocal speech, with the vocabulary, the grammar and, in many cases, the phonology of the local language, especially in the domain of prosody. As far as the tonal languages are concerned, the pitch level characterizes the composition of the syllable and has a phonological signification. In this situation, the whistles transmit two components together in one band of frequency: the characteristics of the melodic line of the spoken words and the characteristics of their articulation. Moreover, it has been shown that whistled forms of non-tonal languages reproduce the phonemes of spoken language by using specific levels of whistle frequencies for the different vowels, whereas specific modulations of the whistle frequency (and sometimes its harmonics) are used for the different consonants in the non-tonal languages (Busnel and Classe 1976) and even in some tonal languages when the tones are not sufficient to get rid of the confusion (Moore, pers. comm. 2003).

Theoretically, the vocabulary of the whistled languages appears infinite. But, as it concerns rural populations, mainly with an oral culture, far from the centers of information, it is not surprising that the collection of words may seem limited to researchers who investigate vocabularies used in the cities. It has been observed that there is not less creation of vocabulary in the whistled speech, but many modern words are not adaptable to local life and therefore are not whistled. Such tendencies are also noticed for the domain of spoken language.

\section{COGNITIVE PROCESSES}

It has been stated that every individual who has been trained with the whistled language of La Gomera for about 3 years obviously reached a high global intelligibility, despite the simplicity of the signal (Luis Maestro, pers. comm. 2003). After sufficient training, for example, $95 \%$ of messages encoded by the 'Silbo' of La Gomera (Busnel et al. 1962b) and $80 \%$ of messages given by the 'Bai' tonal language of China were successfully understood (Xian-Ming 2002). A first study in neuroscience has shown that the Broca Area as well as the Wernicke Area were activated in well-trained listeners, but not in untrained ones, when they were presented with sentences composed of Silbo (Carreiras 2003).

\section{BIOACOUSTICAL COMPARISONS}

Some structural properties of whistled language suggest comparing it to a few other forms of communication. These are given, for instance, by the use of so-called talking musical instruments (TMI) which are found in African cultures and China, or by 


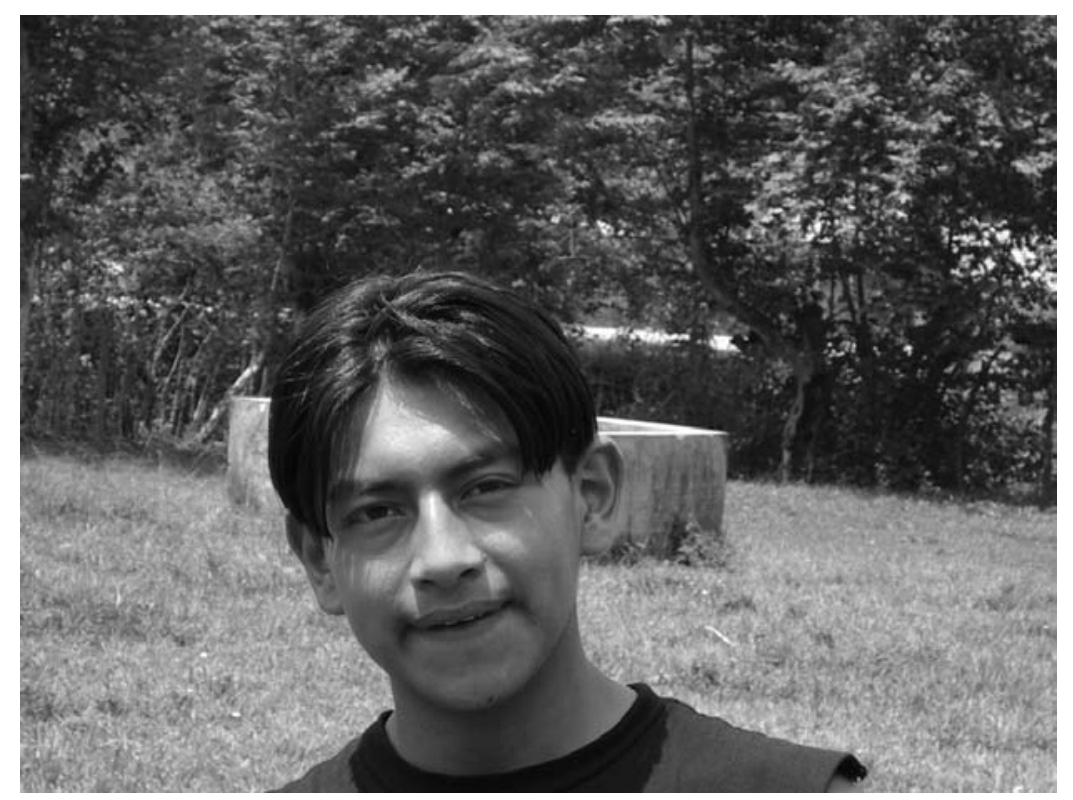

Fig. 3 - Labio-dental technique practiced for Mazateco and Spanish whistled languages in Mexico.

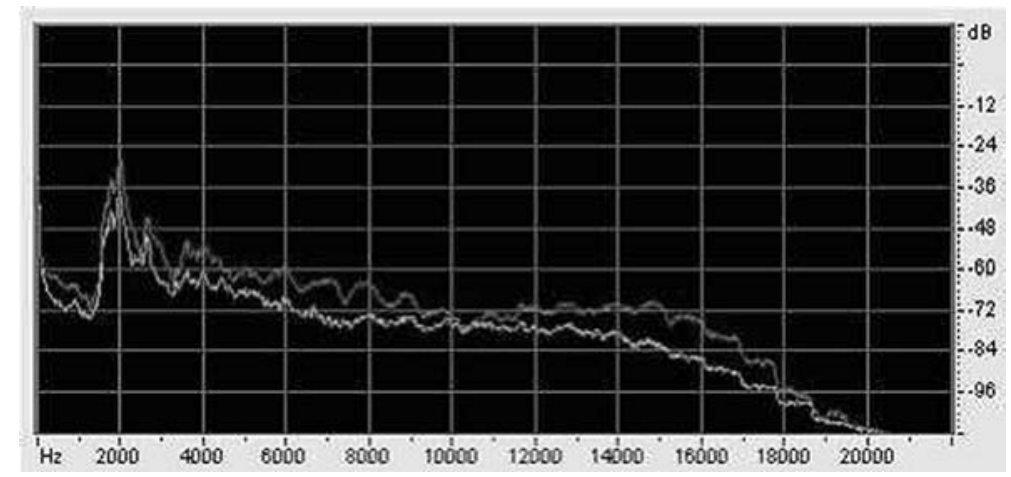

Fig. 4 - Stereo distribution of the frequencies of a Mixteco whistled sentence. The signal that conveys the information at long distance is centered on $2000 \mathrm{~Hz}$.

the application of whistle-like vocalizations which frequently occur even in nonverbal organisms, such as birds, several primates and marine mammals.

The sound of TMIs and similarly whistled languages can be regarded as an abridgment of speech. Thus, comparisons between instrumental sound patterns and whistles could positively influence further studies of language. Cross-comparisons of human and animal whistles, on the other hand, are interest- ing from a different perspective. For example, both classes of whistles serve for long-distance communication mostly (Marler 1955, Busnel 1966; see also Brumm 2004, Oliveira and Ades 2004), but they differ in many other respects, e.g. the way they are produced. Thus, contrasting them could indeed help to sharpen the idiosyncrasy of our own whistles. Such a task, however, requires a formal definition of their acoustical characteristics. 
In human beings, a whistle consists of a narrow frequency band (typically located between 1000 and $3000 \mathrm{~Hz}$ ), which lasts for a certain amount of time and the relevant information it contains resists degradation due to reverberation. This definition could be the same for animal species with particular variations in the frequency level or the degree of frequency modulation.

\section{Human Whistles AND TALKING}

Musical Instruments (TMI)

Many cultures play their native language on instruments, and whistle it too. Each instrument takes advantage of specific aspects of the musical and linguistic transmission. The TMIs have been studied mainly in Africa, but also in Melanesia and in China. It is interesting to consider that these means of communication also convey messages with a linguistic attitude. The technique used for the abridgment of the speech depends on the instrument and on the structure of the local language. Even different strategies have been observed between cultures using similar instruments on similar structures of languages (Stern 1957). From the whistles to the drummed forms of the languages, a continuum of abridgments of speech can be noticed. Therefore it is important to study the acoustical comparison of these different ways of conveying information.

\section{ENDANGERED LANGUAGES}

The extinction of whistled languages in La Gomera, in Aas and currently in Antia in Greece is the direct drawback of the aging rural populations and their progressive weakening through, for example, the disappearance of traditional activities like shepherding. When a culture is threatened, its whistled or played form of speech is one of the first parts of the native language to disappear.

Today, every investigator who studies these forms of communication should contact the Department of Intangible Patrimony of Humanity in the UNESCO in order to be part of the international collaboration between these cultures which fights to enable the next generations to learn and study their own oral richness, but also to learn the endangered status of these played and whistled languages.

The various people using whistle speech constitute a minority culture in the country where they live. They lack official recognition. They have been the victims of different waves of domination. Therefore the native forms of the languages are in danger of disappearing and the cultural knowledge contained in the oral traditions is less and less perpetuated by the new generations.

\section{CONCLUSIONS}

To conclude, whistled languages are products of human intelligence and not just curiosities or "surrogates"' in the pejorative sense. They show a widespread distribution across cultures and have obviously developed quite independently of each other, but mostly related to a particular local environment. They are quite clearly defined and represent an original adaptation of the spoken language, like a 'local cellular phone' for the needs of isolated human groups. They document a cultural heritage and are still fully in use among millions of Mexicans and Chinese, as well as thousands of Turks, Africans and people of Papua New Guinea.

The study of whistled and played languages (e.g. TMI) might be a means by which to better understand the role and the status of prosody in the language faculty and some elements of its evolution linked to musical aspects. They are also particularly convenient for research on the intelligibility of languages and the recognition of an individual signature in speech. Moreover their principles may inspire an alternative development either of systems that convey coded signals or of applications of languages for machines.

The current situation of endangered languages underlines that the cultures they represent are dying. But all of these forms of communication hold secrets about communication in general and therefore when they are in danger, it is also our culture that is in danger. 


\section{ACKNOWLEDGMENTS}

I would like to thank the Engineer Laure Dentel for her constant support, the persons of the Mazateco, Mixteco, Gomero and Bora cultures for their collaboration, René-Guy Busnel, Colette Grinevald and Denny Moore for their advice, Jacques Vielliard and Dietmar Todt for their professionalism and kindness during the preparation of this manuscript.

\section{RESUMO}

Línguas assobiadas são um patrimônio valioso da cultura humana. Este artigo fornece um panorama preliminar da nova abordagem multidisciplinar sobre essas línguas. Estudos anteriores dos equivalentes assobiados de idiomas já mostraram que podem fornecer informações significativas sobre o papel do ritmo e da melodia na linguagem. Para concretizar este papel, a maioria dos assobios consiste em modulações de freqüência em torno de $2000 \mathrm{~Hz}$ $( \pm 1000 \mathrm{~Hz})$ e freqüentemente atingem uma intensidade de cerca de $130 \mathrm{~dB}$ (medido a $1 \mathrm{~m}$ da fonte). $\mathrm{O}$ alcance pode atingir até $10 \mathrm{~km}$ (como verificamos em La Gomera, Ilhas Canárias) e a mensagem pode permanecer inteligível, mesmo que o sinal seja deteriorado. Em certas culturas o uso de linguagem assobiada é associado a certos "instrumentos musicais falantes", (por exemplo, flautas, violões, harpas, gongos, tambores, "khens"). Finalmente, como meio de transmitir informação, os assobios têm algumas analogias no reino animal (como certas aves, cetáceos, primatas), oferecendo oportunidades para comparar as características acústicas dos respectivos sinais. Com essas propriedades como referência, o projeto relatado aqui tem duas tarefas principais: elucidar melhor os diversos aspectos da linguagem assobiada e, sobre tudo, ajudar a interromper imediatamente o processo de seu desaparecimento gradual.

Palavras-chave: línguas humanas assobiadas, comunicação por assobio, processos cognitivos, constantes culturais.

\section{REFERENCES}

Brumm H. 2004. Causes and consequences of song amplitude adjustment in a territorial bird: a case study in nightingales. An Acad Bras Cienc 76: 289-295.

BusNel R-G. 1966. Information in the human whistled language and sea mammal whistling. In: NorRIs KS.
(Ed), Whales, Dolphins and Porpoises. Berkeley and Los Angeles: University of California Press.

BuSNEL R-G. 1970a. Historical briefing of the whistling language of Kusköy. Rev Phonétique Appliquée 14/15: 11-12.

Busnel R-G. 1970b. Recherches expérimentales sur la langue sifflée de Kusköy. Rev Phonétique Appliquée 14/15: 41-57.

Busnel R-G. 1981. Bioacustica de la lengua silbada mazateca. Ciencia y desarrollo 39: 178-184.

Busnel R-G and Classe A. 1976. Whistled languages. Berlin: Springer Verlag.

Busnel R-G And Siegfried JR. 1990. Paroles, langages et langues sifflées. Paris: Service du Film de Recherche Scientifique.

Busnel R-G, Moles A and Vallancien B. 1962a. Un cas de langue sifflée dans les Pyrénées françaises. Logos 5: 76-91.

Busnel R-G, Moles A and Vallancien B. 1962b. Sur l'aspect phonétique d'une langue sifflée dans les Pyrénées françaises. Proc Int Congr Phonetic Sci, Helsinki. The Hage: Mouton, p. 533-546.

Carreiras M. 2003. Activación cerebral durante el procesamiento del silbo gomero. I Congr Int Lenguajes Silbados. La Gomera: Casa cultural de Valley gran rey.

Caughley R. 1976. Chepang Whistle Talk. In: SeBEOK TA AND UMiker J. (Eds), Speech Surrogates: Drum and Whistle Systems. The Hague: Mouton, p. 997-1022.

Charalambakis C. 1993. A Case of Whistled Speech from Greece. In: PhilipPaKi-Warburton I, NicoLAIDIS K. AND Sifianou M. (Eds), Themes in Greek linguistics: papers from the first international conference on Greek linguistics. Amsterdam: John Benjamins Publ Co, p. 389-396.

Classe A. 1956. Phonetics of the Silbo Gomero. Archivum linguisticum 9: 44-61.

Classe A. 1957. The whistle language of La Gomera. Sci Amer 196: 111-124.

Classe A. 1963. Les langues sifflées, squelettes informatifs du langage. In: Moles AA AND VAllanCIEN B. (Eds), Communication et Langage. Paris: Gauthier-Villars. 
Cowan G. 1948. Mazateco whistle speech. Language 24: $280-286$.

Cowan G. 1952. El idioma silbado entre los Mazatecos de Oxaca y las Tepehuas de Hildago. Mexico: Tlatoani I, 31-33.

Cowan G. 1972. Segmental features of Tepehua whistle speech. In: Rigault A and Charbonneau R. (Eds), Proc Int Congr Phonetic Sci, Montréal. Paris: Mouton, p. 695-698.

Cowan G. 1976. Whistled Tepehua. In: SEBeok T AND UMIKER-SEBEOK DJ. (Eds), Speech surrogates: drum and whistle systems. Paris: Mouton, p. 1400-1409.

Cowan G. 1981. Whistled communication. N Linguistics 20: 22-24.

Eвoué F. 1935. La clé musicale des langues tambourinées et sifflées. Bull Comité Afrique occid franç 18: 353-366.

LABouret H. 1923. Langage tambouriné et sifflé. Bull Comité Afrique occid franç 6: 120-158.

LAJARD M. 1891. Le langage sifflé des Canaries. Bull Soc Anthropol Paris 4: 469-483.

LENNEBERG EH. 1970. An acoustic analysis of the Turkish whistling language of Kusköy. Rev Phonétique Appliquée 14/15: 25-39.

Leroy C. 1970. Étude de phonétique comparative de la langue turque sifflée et parlée. Rev Phonétique Appliquée 14/15: 119-161.

MARLER P. 1955. Characteristics of some animal calls. Nature 176: 6-8.
Moreau ML. 1997. La communication sifflée chez les Diola (Casamance, Sénégal). In DiversCite Langues. Vol. II. http://www.uquebec.ca/diverscite.

NeKitel O. 1992. A perceptual analysis of Abu'-Wam whistled speech. In: Dutton T, Tryon D And Ross M. (Eds), Language Game: papers in memory of Don C. Laycock. Canberra: Australian National University, p. 299-311.

Oliveira DAG AND Ades C. 2004. Long-distance calls in Neotropical primates. An Acad Bras Cienc 76: 393-398.

QuedenfeldT HM. 1887. Pfeifsprache auf der Insel Gomera. Zeitschr Ethnol 19: 731-741.

Rialland A and Gautheron B. 2000. Phonologie et phonétique d'un langage sifflé: le silbo gomero. 2nd Round Table in Phonology of the GDR (Groupe De Recherche) 1954. Bordeaux: C.N.R.S.

Sebeok T and Umiker-Sebeok DJ. 1976. Speech surrogates: drum and whistle systems. La Haye and Paris: Mouton.

STERn T. 1957. Drum and whistle languages: an analysis of speech surrogates. Amer Anthropol 59: 487-506.

Trujillo R. 1978. Análisis lingüístico del silbo gomero. Tenerife: Universidad La Laguna.

XIAN-Ming Y. 2002. The talking musical instruments of the province of Yunnan. Ethnomusicology research seminar. London: Goldsmith University. 